\title{
PARTISIPASI MASYARAKAT DALAM PENGELOLAAN AREAL PERLINDUNGAN LAUT - BERBASIS MASYARAKAT DI KABUPATEN ADMINISTRASI KEPULAUAN SERIBU, DKI JAKARTA
}

\section{Community's Participation in Managing Community Based - Marine Protected Area in Kepulauan Seribu District, DKI Jakarta.}

\author{
Erwiantono', Siti Amanah'2, Pang S. Asngari ${ }^{2}$, Rilus A. Kinseng ${ }^{2}$ \\ 1 Jurusan Sosial Ekonomi Perikanan, FPIK Universitas Mulawarman - Samarinda \\ ${ }^{2}$ Departemen Sains Komunikasi dan Pengembangan Masyarakat, FEMA IPB - Bogor \\ Email: ewin_bebek@yahoo.com \\ Diterima 22 April 2013 - Disetujui 22 Nopember 2013
}

\begin{abstract}
ABSTRAK
Pada dua dekade terakhir, kondisi ekosistem terumbu karang di perairan Kepulauan Seribu telah menunjukkan degradasi yang mengkawatirkan. Untuk mengatasi permasalahan tersebut, mulai tahun 2004 Pemda Kabupaten Administrasi Kepulauan Seribu bersama masyarakat menerapkan program Areal Perlindungan Laut-Berbasis Masyarakat (APL-BM) di lima kelurahan. Tujuan penelitian adalah : (1) menganalisis tingkat partisipasi masyarakat dalam pengelolaan APL-BM, dan; (2) menganalisis faktor - faktor yang berpengaruh terhadap partisipasi masyarakat. Pengumpulan data dilakukan selama periode Juni 2011-Mei 2012 dengan menggunakan kuesioner, pengamatan dan kajian pustaka. Populasi pada penelitian ini adalah individu pemanfaat utama sumberdaya alam berbasis ekosistem terumbu karang secara langsung. Metode pengambilan contoh yang digunakan adalah acak berproporsi sehingga terpilih 202 responden. Data dianalisis dengan menggunakan statistika deskriptif dan inferensia dengan model persamaan struktural (SEM). Hasil penelitian menunjukkan : (1) tingkat partisipasi masyarakat dalam pengelolaan APL-BM pada keseluruhan tahapan kegiatan adalah rendah dan (2) faktor - faktor yang berpengaruh terhadap tingkat partisipasi masyarakat adalah kemampuan organisasi dan motivasi masyarakat. Kedua faktor tersebut dipengaruhi oleh indikator pendekatan komunikasi, kesesuaian konsepsi program dan intensitas peran penyuluhan.
\end{abstract}

Kata Kunci: tingkat partisipasi, daerah perlindungan laut berbasis masyarakat

\begin{abstract}
In the last two decades, the coral reef ecosystem in Kepulauan Seribu has shown a significant degradation. Considered this, in 2004 the government of Kepulauan Seribu District initiated collaborative program in five villages and the program called as community based-marine protected area. The research objectives were: (1) to analyze community's participation level in managing marine protected area in Kepulauan Seribu District and (2) to analyze the determinant factors that influence the community's participation. The data were collected from June 2011 - May 2012 by using questionnare, observation and reviewing existing documents. Units of analizing were 202 respondents of primary stakeholders that utilize fisheries-marine resources directly. The data were analyzed using descriptive and inferential statistics based on structural equation modelling (SEM). The conclusions of the study are: (1) the level of community's participation in managing marine protected is low and (2) this condition is influenced by community organisation's ability and community's motivation. Community organisation's ability and motivation are in low level. The factors which influence community organisation's' ability and community's motivation are communication approaches, the compatibility of program conception and intensity of extention agents roles.
\end{abstract}

Keywords: participation level, community based marine protected area 


\section{PENDAHULUAN}

Kualitas ekosistem terumbu karang di Kepulauan Seribu saat ini umumnya dikategorikan dalam kondisi rusak hingga sedang. Penelitian Yayasan Terangi menunjukkan bahwa rerata tutupan karang hidup adalah sebesar $32,69 \%$ pada tahun 2004, 33,61 \% pada tahun 2005 dan 31,33 \% pada tahun 2007. Apabila penurunan kualitas ekosistem terumbu karang ini tidak segera ditangani maka akan semakin berakibat buruk bagi pendapatan dan kesejahteraan masyarakat di wilayah tersebut (Terangi, 2009).

Diperlukan suatu konsepsi pengelolaan yang tepat untuk mengatasi masalah-masalah kerusakan serta menjaga sumberdaya dan ekosistem pesisir-kelautan secara berkelanjutan. Salah satu upaya memperkuat inisiatif masyarakat agar mengambil peran yang lebih besar dalam mengelola sumberdaya pesisir adalah dengan mengembangkan daerah perlindungan laut berbasis masyarakat (co-management) oleh masyarakat, pemerintah setempat serta pemangku kepentingan lainnya. Konsep ini berangkat dari pemahaman bahwa masyarakat memiliki kemampuan untuk memperbaiki kualitas hidupnya sehingga yang diperlukan adalah dukungan untuk mengelola sumberdaya sesuai dengan kebutuhannya (Hartoto dkk., 2009).

Mempertimbangkan laju kerusakan sumberdaya perikanan dan kelautan yang terus terjadi di wilayah perairan Kepulauan Seribu, pada tahun 2004 pemerintah daerah setempat melalui Suku Dinas Kelautan-Perikanan Kabupaten Administrasi Kepulauan Seribu dan masyarakat sepakat untuk menerapkan program Areal Perlindungan Laut Berbasis Masyarakat (APLBM) di Kelurahan Pulau Panggang. Program ini kemudian juga diterapkan pada empat kelurahan lainnya yaitu Kelurahan Pulau Harapan, Pulau Kelapa, Pulau Tidung dan Pulau Pari. Konsep dasar dari program APL-BM adalah membebaskan kawasan tertentu dari aktivitas yang dapat mempengaruhi kemampuan ekosistem perairan laut untuk memulihkan diri secara alamiah. Pengelolaan kawasan APL-BM dilakukan secara kolaboratif bersama antara pemerintah, masyarakat dan stakeholder lainnya.

Hingga saat ini, kemauan, kemampuan serta peluang masyarakat untuk berperan aktif dalam mengelola sumberdaya belum berjalan optimal dan masih terkendala berbagai faktor.
Fauzi dan Buchary (2002) mengemukakan fakta terjadi kesenjangan partisipasi masyarakat dan komunikasi dalam pengelolaan sumberdaya perikanan-kelautan di wilayah Taman Nasional Laut Kepulauan Seribu. Pendapat serupa dikemukakan oleh Clifton (2003), Sangadji (2010) dan Glaser et al. (2010) bahwa partisipasi masyarakat dalam pengelolaan daerah perlindungan laut di Indonesia berada dalam kategori rendah dan menghadapi berbagai kendala dalam pengembangannya.

Belum optimalnya partisipasi masyarakat pada pelaksanaan program APL-BM dalam pengelolaan sumberdaya perikanan dan kelautan di wilayah Kepulauan Seribu saat ini merupakan akibat dari interaksi berbagai faktor. Faktor partisipasi masyarakat adalah satu di antara faktor utama yang mempengaruhi keberhasilan program daerah perlindungan laut, sehingga penting untuk dilakukan kajian yang menganalisa kinerja partisipasi masyarakat dalam implementasi program. Berdasarkan uraian tersebut, tujuan penelitian dirumuskan sebagai berikut : (1) menganalisis tingkat partisipasi masyarakat dalam upaya pengelolaan APL-BM di wilayah Kabupaten Administrasi Kepulauan Seribu dan (2) menganalis faktor-faktor yang mempengaruhi tingkat partisipasi masyarakat dalam pengelolaan APL-BM.

\section{METODE PENELITIAN}

\section{Kerangka Pemikiran}

Paradigma baru pembangunan perikanan dan kelautan yang merupakan koreksi terhadap paradigma lama yang kurang memperhatikan keberadaan dan peran masyarakat sekitar pesisir. Paradigma baru ini berupaya menempatkan masyarakat sebagai pelaku utama pembangunan. Masyarakat tidak lagi dilihat sebagai obyek pembangunan, melainkan dilihat sebagai subyek yang aktif yang memiliki inisiatif, kemauan dan kemampuan dalam mengelola dan melestarikan sumberdaya perikanan-kelautan. Paradigma ini telah memberikan peluang dan ruang gerak yang lebih luas kepada masyarakat pesisir untuk ikut terlibat atau berpartisipasi dalam pengelolaan sumberdaya. Dengan partisipasi seperti ini maka akan timbul rasa memiliki (sense of belonging) dan rasa tanggung jawab (sense of responsibility) atas keberhasilan kegiatan pengelolaan sumberdaya. Partisipasi masyarakat 
yang utuh dan menyeluruh adalah jaminan keberlanjutan program pembangunan.

Partisipasi masyarakat dalam pembangunan memerlukan persyaratan kemampuan tertentu dalam pelaksanaannya (Alpizar, 2006; Pomeroy dan Rivera-Guieb, 2006). Partisipasi dalam mengelola sumberdaya perikanan dan kelautan melalui program APL-BM tidak dapat berlangsung sebagaimana yang diharapkan apabila kelompokkelompok masyarakat pemanfaat yang terlibat tidak memiliki kemampuan yang memadai.
Partisipasi masyarakat dalam pengelolaan sumberdaya perikanan dan kelautan pada dasarnya didorong oleh adanya motivasi untuk memperoleh sesuatu dari partisipasi tersebut (Zanettel dan Knuth, 2004). Motivasi bersifat fluktuatif serta mengalami modifikasi karena pengaruh pengalaman dan pola perkembangan kepribadiannya. Proses belajar dalam diri seseorang pada umumnya dipengaruhi faktor internal yang bersifat fungsional dan faktor eksternal yang bersifat struktural (Amanah, 2006; Aldon et al., 2011). Gambar 1 menampilkan kerangka penelitian.

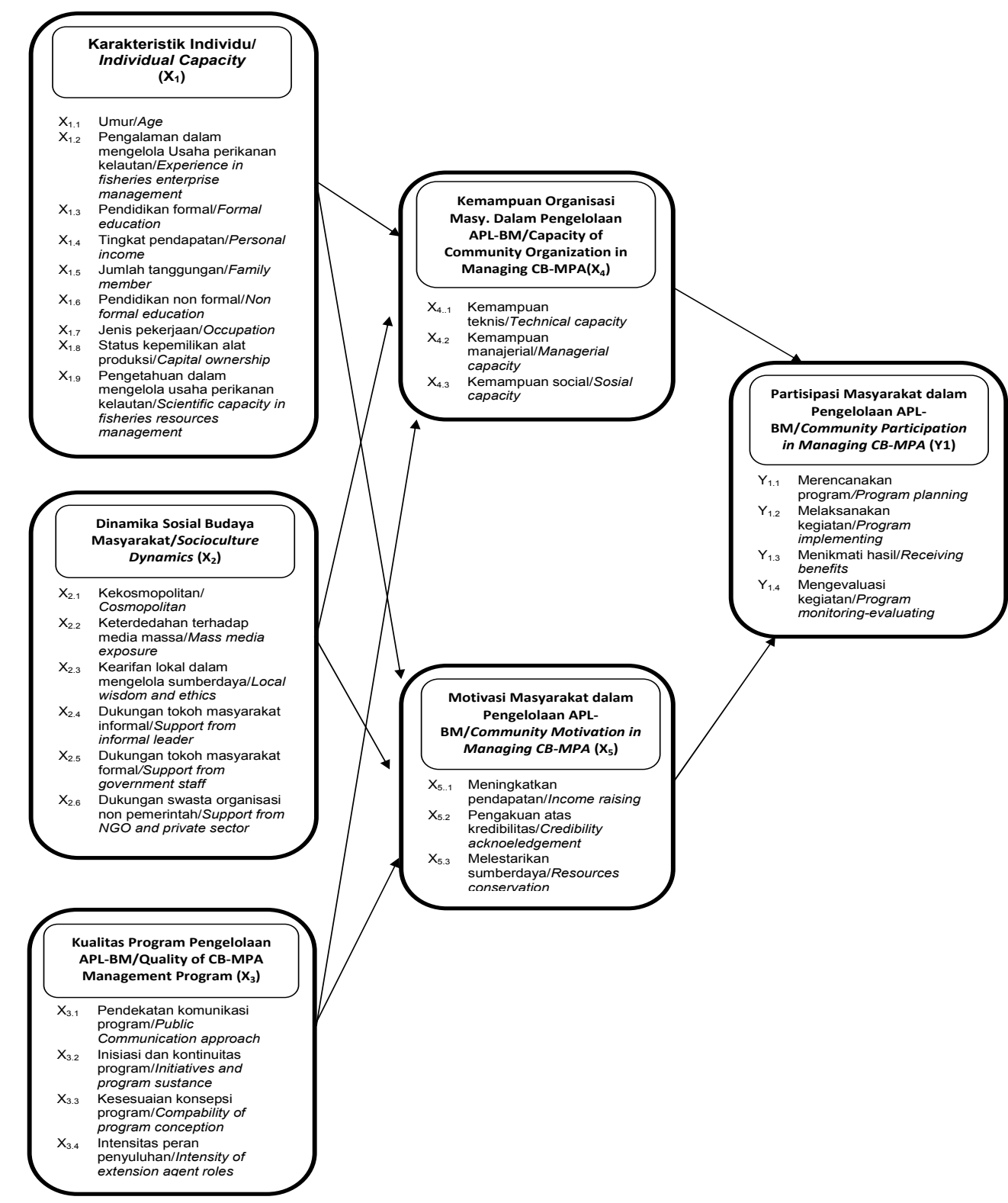

Gambar 1. Kerangka pemikiran penelitian partisipasi masyarakat dalam pengelolaan areal Perlindungan Laut - Berbasis Masyarakat di Kabupaten Administrasi Kepulauan Seribu, DKI Jakarta.

Figure 1. Logical Framework Correlating Different Indicators In Analyzing Community Participation in CB-MPA in Kepulauan Seribu, DKI Jakarta. 


\section{Rancangan Penelitian}

Rancangan penelitian yang digunakan adalah survei deskriptif eksplanatori yang bersifat menjelaskan suatu fenomena, fakta-fakta dan gejala yang ada pada suatu tempat serta mencari keterangan secara faktual tentang berbagai hal tersebut dengan menguji model teoritiknya (Nazir, 1985; Singarimbun dan Effendie, 2006). Penelitian dilaksanakan di lima kelurahan yang memiliki program APL-BM, Kabupaten Administratif Kepulauan Seribu, DKI Jakarta. Populasi penelitian ini adalah seluruh individu yang memanfaatkan secara langsung sumberdaya perikanan dan kelautan berbasis ekosistem terumbu karang sebagai sumber utama penghidupannya (pimary stakeholders) di lokasi penelitian. Sebanyak 202 responden dipilih dengan tehnik acak proporsional (proportional random sampling). Data primer dikumpulkan dengan menggunakan kuesioner yang dibuat berdasarkan skala Likert berskala empat dan data sekunder dikumpulkan melalui analisis dokumen serta publikasi dari lembaga terkait.

Pengolahan dan analisis data dilakukan menggunakan statistik deskriptif dan statistik inferensial. Statistik deskriptif digunakan dalam rangka memberikan gambaran mengenai sebaran responden pada setiap peubah dengan memakai tabel distribusi frekwensi. Selanjutnya untuk melakukan estimasi atau pendugaan atau populasi (generalisasi) dalam rangka melihat sejauh mana peubah bebas mempengaruhi peubah terikat serta untuk melihat kecocokan model penelitian yang dirancang (model hipotetik) dengan model sesungguhnya, digunakan statistik inferensial yaitu menggunakan SEM (structural equation modelling). Pengolahan dan analisis data menggunakan bantuan program SPSS dan LISREL. Untuk memudahkan analisis dan pengolahan data makan terlebih dahulu disusun model hipotetik persamaan struktural, dengan mengacu pada kerangka berpikir sehingga terlihat jelas jalur pengaruh antara peubah laten eksogen (X1, X2, X3,X4 dan X5) dan peubah laten endogen ( $\mathrm{Y} 1$ ) dengan indikator refleksinya terlihat pada Gambar 1.

\section{HASIL DAN PEMBAHASAN}

\section{Gambaran Umum Wilayah Penelitian}

Kepulauan Seribu yang terletak di Laut Jawa dan Teluk Jakarta merupakan wilayah dengan karakteristik dan potensi alam yang berbeda dengan wilayah DKI Jakarta lainnya. Wilayah ini pada dasarnya tersusun oleh ekosistem pulau-pulau sangat kecil dan perairan laut dangkal yang terdiri dari gugus kepulauan dengan 110 pulau sangat kecil, 86 gosong pulau dan hamparan laut dangkal yang terdiri dari laguna, selat, teluk, terumbu karang tipe fringing reef dan reef flat, mangrove dan lamun di sekitar pulaunya. Dari jumlah pulau yang berada di dalam kawasan perairan tersebut diantaranya 20 pulau sebagai pulau wisata yang dikelola perorangan atau badan usaha dan 11 pulau sebagai hunian penduduk (Terangi, 2009).

Jenis-jenis karang yang umum ditemukan adalah jenis karang keras (hard coral) seperti karang batu (massive coral) misalnya Monstastrea dan Labophyllia, karang meja (Table coral), karang kipas (Gorgonia), karang daun (Leaf coral), karang jamur (Mushroom coral) dan jenis karang lunak (Soft coral). Jenis ikan hias yang banyak ditemukan diantaranya adalah jenis-jenis yang termasuk dalam famili Chaetodontidae, Apogonidae dan Pomancanthidae, sedangkan jenis ikan konsumsi yang bernilai ekonomis tinggi antara lain adalah baronang (Family Siganidae), ekor kuning (Family Caesiodiae), kerapu (Family Serranidae) dan tongkol (Eutynus Sp.).

Saat ini kondisi ekosistem terumbu karang Kepulauan Seribu sangat memprihatinkan, terutama di pulau-pulau yang berdekatan dengan daratan Jawa. Porsi terbesar kerusakan terumbu karang adalah akibat kegiatan manusia di antaranya adalah penangkapan ikan yang merusak dan berlebih, pencemaran air, penimbunan sampah, penambangan pasir dan karang serta penebangan hutan mangrove (Terangi, 2009).

Mempertimbangkan laju kerusakan sumberdaya perikanan dan kelautan yang terus terjadi tersebut, pada tahun 2004 pemerintah dan masyarakat secara sepakat untuk menetapkan program APL-BM di lima kelurahan. Pada areal inti perlindungan dilakukan upaya khusus konservasi dengan melakukan kegiatan tranplantasi karang dan restocking ikan. Areal inti juga dikelilingi pelampung sebagai penanda batas dengan areal penyangga dan pemanfaatan yang berada di luarnya. Konsep dasar dari APL-BM adalah membebaskan kawasan dari aktivitas yang dapat mempengaruhi kemampuan ekosistem perairan laut untuk memulihkan diri secara alamiah. Dalam keputusan tersebut disebutkan bahwa pengelolaan kawasan APL-BM tersebut dilakukan secara kolaboratif bersama antara pemerintah, masyarakat 
dan pemangku kepentingan lainnya. Zonasi APLBM di Kabupaten Administrasi Kepulauan Seribu berdasarkan SK. Bupati No. 357 / 2004 adalah :

1. Areal inti: merupakan areal di mana pada lokasi tersebut tidak boleh dilakukan kegiatan pemanfaatan apapun, kecuali aktivitas untuk kepentingan konservasi. Areal inti merupakan areal tempat memelihara fungsi ekologis perairan laut

2. Areal penyangga: merupakan areal yang ditetapkan untuk melindungi areal inti. Areal ini dapat dimanfaatkan untuk aktivitas lain yang jenis dan waktu pemanfatannya disesuaikan dengan norma - norma yang ditetapkan masyarakat setempat.

3. Areal pemanfaatan: merupakan areal yang dapat dimanfaatkan untuk kegiatan penangkapan dengan alat tangkap yang tidak merusak lingkungan dan menggunakan bahan yang dilarang.
Pada saat dilakukan penelitian, kualitas ekosistem terumbu karang pada areal inti perlindungan menunjukkan kondisi yang beragam. Kondisi kualitas ekosistem terumbu karang di Kelurahan Pulau Tidung tersebut tergolong dalam kategori paling baik (Tabel 1).

Selain menerapkan program APL - BM dengan areal perlindungan khusus, Pemda Kabupaten Administrasi Kepulauan Seribu sejak tahun 2005 juga melakukan program rehabilitasi ekosistem terumbu karang di areal pemanfaatan, melalui aktivitas penenggelaman terumbu buatan (fish shelter). Fish shelter adalah struktur benda padat buatan manusia yang ditenggelamkan di perairan dengan tujuan menjadi tempat perlindungan dan berkumpulnya ikan di dalam atau di sekitar struktur tersebut.

Fish shelter ditenggelamkan di sejumlah lokasi yang terumbu karangnya mengalami kerusakan atau yang perairannya ditengarai

Tabel 1. Sebaran Kualitas Ekosistem Terumbu karang di Areal Inti APL-BM.

Tabel 1. Distribution of Coral Reef Quality in Core Zone of Comunity Based_Marine Protected Area (CB-MPA).

\begin{tabular}{|c|c|c|c|c|c|}
\hline \multirow{2}{*}{$\begin{array}{c}\text { Kriteria } \\
\text { Kualitas Ekosistem/ } \\
\text { Criterias of Ecosystem } \\
\text { Quality }\end{array}$} & \multicolumn{5}{|c|}{ Lokasi APL-BM/Location of CB-MPA } \\
\hline & Panggang & Harapan & Kelapa & Tidung & Pari \\
\hline $\begin{array}{l}\text { Tutupan karang keras (\%)/ } \\
\text { Hard coral cover(\%) }\end{array}$ & 40.67 & 24.33 & 59.50 & 61.56 & 42.58 \\
\hline $\begin{array}{l}\text { Indeks kematian karang } \\
(0-1) / \text { Coral mortality index } \\
(0-1)\end{array}$ & 0.44 & 0.63 & 0.64 & 0.19 & 0.34 \\
\hline
\end{tabular}

Sumber : Laporan Monitoring - Evaluasi Ekosistem Laut Kepulauan Seribu. 2011

Source : Report of Monitoring and Evaluation for Marine Ecosystem in Kepulauan Seribu. Sub-Bureau for Marine and Agricultural Affairs of Kepulauan Seribu 2011

Tabel 2. Sebaran Komunitas Ikan Terumbu Karang pada Fish Shelter.

Tabel 2. Distribution of Coral Reef's Fish in Fish Shelter.

\begin{tabular}{|c|c|c|c|c|c|}
\hline \multirow[t]{2}{*}{ Kriteria/Criterias } & \multicolumn{5}{|c|}{ Lokasi Fish ShelterlLocation of Fish Shelter } \\
\hline & Panggang & Harapan & Kelapa & Tidung & Pari \\
\hline $\begin{array}{l}\text { Distribusi Jenis ikan/ } \\
\text { Fish Distribution }\end{array}$ & $\begin{array}{c}13 \text { famili / } \\
\text { families. } 16 \\
\text { spesies / } \\
\text { species }\end{array}$ & $\begin{array}{l}10 \text { famili / } \\
\text { families. } \\
33 \text { spesies/ } \\
\text { species }\end{array}$ & $\begin{array}{c}5 \text { famili / } \\
\text { families. } \\
12 \text { spesies / } \\
\text { species }\end{array}$ & $\begin{array}{c}12 \text { famili / } \\
\text { families. } \\
35 \text { spesies/ } \\
\text { species }\end{array}$ & $\begin{array}{c}14 \text { famili / } \\
\text { families. } \\
26 \\
\text { spesies/ } \\
\text { species }\end{array}$ \\
\hline $\begin{array}{l}\text { Jumlah pengamatan/ } \\
\text { Total observation }\end{array}$ & 240 & 585 & 237 & 702 & 530 \\
\hline
\end{tabular}

Sumber : Laporan Monitoring - Evaluasi Ekosistem Laut Kepulauan Seribu. 2011

Source : Report of Monitoring and Evaluation for Marine Ecosystem in Kepulauan Seribu. Sub-Bureau for Marine and Agricultural Affairs of Kepulauan Seribu. 2011 
mengalami kelangkaan ikan. Hasil dari kegiatan ini diharapkan dapat memperbaiki sumberdaya perikanan dan kelautan secara lestari di wilayah Kepulauan Seribu. Keragaan produktivitas sumberdaya perikanan pada fish shelter di Kepulauan Seribu disajikan pada Tabel 2.

\section{Karakteristik Pemanfaat Sumber Daya Perikanan - Kelautan}

Karakteristik individu responden secara mayoritas adalah berusia dewasa muda (rataan usia 37,8 tahun), memiliki tingkat pendidikan formal tingkat menengah (rataan durasi pendidikan formal 7,4 tahun) dan tingkat pendidikan non formal rendah (rataan durasi pendidikan non formal setara 7,6 jam pelatihan), berpenghasilan rendah (rataan pendapatan Rp. 1.893.470), memiliki tanggungan keluarga rendah (rataan tanggungan keluarga 2,9 jiwa). Mayoritas responden memiliki rataan tingkat pengalaman 18,5 tahun, bekerja sebagai nelayan dengan alat tangkap pancing $(31,1 \%)$, berstatus sebagai pekerja dalam struktur relasi kerja $(65$ $\%)$ serta memiliki pengetahuan cukup dalam pengelolaan sumberdaya $(47,4 \%)$.

\section{Dinamika Sosial Budaya Masyarakat}

Secara umum, responden tergolong sebagai individu dengan tingkat kekosmoplitan rendah $(76,1 \%)$ dengan tingkat keterdedahan media massa yang rendah pula $(64,3 \%)$. Hasil penelitian menunjukkan mayoritas responden (57,3\%) berpenilaian dukungan kearifan lokal berpengaruh rendah terhadap pengelolaan program APL-BM. Terdapat $50,4 \%$ responden menilai dukungan tokoh masyarakat informal dikategorikan rendah, $60,5 \%$ responden menilai bahwa dukungan tokoh masyarakat rendah dan $68,1 \%$ responden menilai dukungan organisasi non pemerintah dan swasta rendah dalam pengelolaan APL-BM.

\section{Kualitas Program Pengelolaan APL-BM}

Mayoritas responden beranggapan bahwa kualitas program APL-BM berada pada kategori rendah pada tiga indikator penilaian dan kategori sedang pada satu indikator lainnya. Terdapat sebanyak $67,7 \%$ responden menilai rendah pada indikator kualitas pendekatan komunikasi, 85,6 \% responden menilai rendah pada indikator kualitas inisiatif dan kontinuitas program serta 68,4\% responden menilai rendah pada indikator kualitas kesesuaian konsepsi program. Pada penilaian berkaitan dengan aspek dampak intensitas peran penyuluhan, terdapat $53,1 \%$ responden memberikan penilaian sedang.

\section{Kemampuan Organisasi Masyarakat dalam Pengelolaan APL-BM}

Tingkat kemampuan organisasi masyarakat dalam menjalankan perannya sebagai fasilitator program APL-BM dinilai responden berada dalam tingkat rendah menuju sedang, dicirikan oleh indikator kemampuan teknis yang dipersepsikan dengan tingkat sedang oleh 58,0 \% responden, indikator tingkat kemampuan manajerial dipersepsikan rendah oleh 55,3\% responden dan aspek kemampuan sosial yang juga dipersepsikan rendah oleh $50,4 \%$ responden.

\section{Motivasi Responden untuk Berpartisipasi Dalam Pengelolaan APL-BM}

Mayoritas responden tergolong memiliki tingkat motivasi sedang pada tiga indikator yang digunakan untuk mengukur motivasi yaitu motivasi untuk meningkatkan pendapatan (58,9\%), mendapatkan pengakuan atas kredibilitas (56,9\%) dan melestarikan sumberdaya $(51,5 \%)$.

\section{Tingkat Partisipasi Masyarakat dalam Pengelolaan APL-BM}

Tingkat partisipasi masyarakat dalam pengelolaan APL-BM tergolong rendah pada semua tahapan partisipasi. Terdapat $67,2 \%$ responden yang menunjukkan tingkat partisipasi rendah pada tahapan merencanakan kegiatan, 58,6 \% responden berpartisipasi rendah pada tahapan melaksanakan kegiatan, 62,8 \% responden berpartisipasi rendah pada tahapan menikmati hasil kegiatan dan 52,1\% berpartisipasi rendah pada tahapan mengevaluasi kegiatan (Tabel 3).

\section{Partisipasi pada tahapan merencanakan kegiatan}

Perencanaan merupakan langkah awal yang penting bagi keberhasilan suatu kegiatan. Perencanaan yang baik dan sistematis dapat memberikan arah dan menjadi pedoman bagi berlangsungnya suatu kegiatan. Secara umum, tingkat partisipasi resnponden dalam tahapan perencanaan kegiatan APL-BM di lima kelurahan Kepulauan Seribu tergolong rendah. Sebagian besar responden jarang menghadiri pertemuan yang diadakan dalam rangka membuat perencanaan program kerja APL-BM karena merasa tidak diundang. 
Tabel 3. Sebaran Tingkat Partisipasi Masyarakat dalam Pengelolaan APL - BM . Tabel 3. Distribution of Community Participation Level in Managing CB-MPA.

\begin{tabular}{|c|c|c|c|c|c|c|}
\hline \multirow{2}{*}{$\begin{array}{l}\text { Tingkat Partisipasi } \\
\text { Masyarakat/ } \\
\text { Community } \\
\text { Participation Level }\end{array}$} & \multicolumn{5}{|c|}{ Kelurahan/Villages } & \multirow[b]{2}{*}{$\begin{array}{l}\text { Total } \\
\%\end{array}$} \\
\hline & $\begin{array}{l}\text { Panggang } \\
(\%)\end{array}$ & $\begin{array}{l}\text { Harapan } \\
\text { (\%) }\end{array}$ & $\begin{array}{l}\text { Kelapa } \\
(\%)\end{array}$ & $\begin{array}{l}\text { Tidung } \\
(\%)\end{array}$ & $\begin{array}{l}\text { Pari } \\
(\%)\end{array}$ & \\
\hline \multicolumn{7}{|c|}{$\begin{array}{l}\text { Tingkat partisipasi dalam merencanakan kegiatan/ } \\
\text { Community Participation Level in Planning Activities }\end{array}$} \\
\hline Rendah /Low & 63.6 & 78.6 & 71.0 & 53.2 & 69.5 & 67.2 \\
\hline Sedang /Middle & 20.0 & 13.3 & 14.5 & 26.3 & 17.0 & 18.2 \\
\hline Tinggi/High & 16.4 & 8.1 & 14.5 & 20.5 & 13.5 & 14.6 \\
\hline $\begin{array}{l}\text { Rataan skor/ Scores } \\
\text { Average }\end{array}$ & 10.5 & 10.5 & 10.0 & 12.0 & 10.1 & 10.8 \\
\hline \multicolumn{7}{|c|}{$\begin{array}{l}\text { Tingkat partisipasi dalam melaksanakan kegiatan/ Community Participation Level in Implementing } \\
\text { Activities }\end{array}$} \\
\hline Rendah /Low & 67.3 & 67.1 & 75.5 & 13.2 & 69.8 & 58.6 \\
\hline Sedang /Middle & 23.6 & 20.6 & 24.5 & 76.8 & 20.2 & 33.1 \\
\hline Tinggi/High & 9.1 & 12.3 & 0.0 & 10.0 & 10.0 & 8.3 \\
\hline $\begin{array}{l}\text { Rataan skor/ } \\
\text { Scores Average }\end{array}$ & 12.6 & 12.1 & 12.0 & 16.2 & 12.3 & 12.4 \\
\hline \multicolumn{7}{|c|}{$\begin{array}{l}\text { Tingkat partisipasi dalam menikmati kegiatan/ } \\
\text { Community ParticipationLevel in Gaining Benefit Activities }\end{array}$} \\
\hline Rendah /Low & 67.3 & 62.8 & 79.6 & 36.8 & 67.6 & 62.8 \\
\hline Sedang /Middle & 20.0 & 28.6 & 15.9 & 43.2 & 25.4 & 26.6 \\
\hline Tinggi/High & 12.7 & 8.6 & 4.5 & 20.0 & 7.0 & 10.6 \\
\hline $\begin{array}{l}\text { Rataan skor/ Scores } \\
\text { Average }\end{array}$ & 2.2 & 2.4 & 2.1 & 4.3 & 2.5 & 2.4 \\
\hline \multicolumn{7}{|c|}{$\begin{array}{l}\text { Tingkat partisipasi dalam mengevaluasi kegiatan/ } \\
\text { Community Participation Level in Monev Activities }\end{array}$} \\
\hline Rendah /Low & 47.3 & 62.9 & 55.4 & 36.2 & 58.7 & 52.1 \\
\hline Sedang /Middle & 32.7 & 33.3 & 32.3 & 43.2 & 28.6 & 34.0 \\
\hline Tinggi/High & 20.0 & 13.8 & 12.3 & 20.5 & 12.7 & 13.9 \\
\hline $\begin{array}{l}\text { Rataan skor/ Scores } \\
\text { Average }\end{array}$ & 12.6 & 10.3 & 10.0 & 14.3 & 10.5 & 10.7 \\
\hline
\end{tabular}

Sumber : data primer. diolah/Source : Primary data processed

Pada saat menghadiri pertemuan, responden cukup aktif dalam memberikan kontribusi pemikiran berupa masukan atau sanggahan, tetapi responden merasa tidak mendapat apresiasi yang memuaskan. Hambatan ini berdampak pada susunan program kerja yang juga dianggap tidak sesuai dengan situasi yang sesungguhnya berkembang di lapangan dalam pandangan responden. Secara statistik tidak terdapat perbedaan signifikan pada tingkat partisipasi dalam merencanakan kegiatan APL-BM di lima kelurahan yang diteliti.

\section{Partisipasi pada tahapan melaksanakan kegiatan pengelolaan APL-BM}

Secara umum, tingkat partisipasi resnponden dalam tahapan pelaksanaan kegiatan APL - BM di wilayah Kepulauan Seribu tergolong dalam tingkat rendah. Sebagian besar responden tidak pernah ikut berkontribusi menyumbangkan uang dan alat - bahan yang diperlukan dalam pelaksanaan kegiatan penglolaan APL-BM, tetapi responden tidak berkeberatan jika diminta memberikan kontribusi tenaga kerja. Alasan responden adalah selama ini tidak ada penjelasan yang memuaskan tentang skema kebutuhan dana dan sarana prasarana dalam pengelolaan APL-BM serta bagaimana proporsi kontribusi dari para pemangku kepentingan yang ada.

Rendahnya partisipasi pada tahap pelaksanaan kegiatan pengelolaan APL-BM juga diindikasikan oleh rendahnya kepatuhan dalam mentaati peraturan tentang aktivitas yang diijinkan pada zonasi APL-BM. Pelanggaran 
yang paling sering terjadi adalah dilakukannya dilakukannya aktivitas pemanfaatan ekstraktif di areal inti perlindungan. Responden tidak menegur dan melaporkan tindakan pelanggaran dari pihak lain yang mereka lihat karena tidak memahami prosedur penertiban yang berlaku dalam lingkup kerja APL-BM di wilayah kelurahannya sendiri maupun di wilayah kelurahan lain.

Secara statistik terdapat perbedaan signifikan pada tingkat partisipasi dalam melaksakan kegiatan APL-BM di Kelurahan Pulau Tidung dengan ke empat kelurahan lainnya yang diteliti. Hal ini berhubungan dengan ketegasan organisasi pengelola dan anggota masyarakat dalam menegakkan peraturan yang berlaku, baik terhadap warga dari kelurahannya sendiri maupun dari kelurahan lain yang datang ke wilayah mereka.

Partisipasi pada tahapan menikmati hasil kegiatan pengelolaan APL-BM

Sebagian besar responden menunjukkan tingkat partisipasi rendah dalam tahapan menikmati hasil kegiatan APL-BM di wilayah Kepulauan Seribu. Sebagian besar responden, terutama yang memiliki pekerjaan sebagai nelayan tradisional tidak merasakan adanya peningkatan hasil tangkapan dan pendapatan yang signifikan sebagai dampak positif dari kegiatan pengelolaan APL-BM. Sementara itu, minoritas responden dari bidang kerja ekowisata dan budidaya karang komersial merasakan manfaat postitif dari kegiatan APL-BM karena pekerjaan tersebut adalah alternatif pekerjaan baru yang tumbuh terkait dengan implementasi program APL-BM baik secara langsung maupun tidak langsung.

Secara statistik terdapat perbedaan signifikan pada tingkat partisipasi dalam melaksakan kegiatan APL-BM di Kelurahan Pulau Tidung dengan ke empat kelurahan lainnya. Hal ini disebabkan karena responden di Kelurahan Pulau Tidung merasakan manfaat nyata dari penerapan program APL-BM di kelurahannya. Mayoritas responden di Kelurahan Pulau Tidung bekerja sebagai nelayan pancing dan pemandu wisata. Responden beranggapan kualitas terumbu karang terjaga di wilayahnya terjaga dengan baik sehingga meningkatkan produktivitas berupa ikan hasil tangkapan yang memadai serta pada saat yang bersamaan usaha ekowisata berkembang dengan pesat adalah dua faktor utama yang bekerja secara simultan dalam meningkatkan manfaat dari pengelolaan APL-BM.
Periode hari kerja dimanfaatkan nelayan pancing untuk kegiatan penangkapan ikan yang hasilnya dijual pada pengelola usaha ekowisata untuk kemudian disimpan guna memenuhi pesanan konsumsi wisatawan pada akhir pekan. Sedangkan pada akhir pekan para nelayan pancing akan dilibatkan oleh para operator wisata sebagai mitra pemandu bagi wisatawan yang ingin merasakan wisata pemancingan di Kepulauan Seribu.

\section{Partisipasi pada tahapan mengevaluasi kegiatan pengelolaan APL-BM}

Tahapan mengevaluasi kegiatan merupakan langkah akhir dari siklus kegiatan, di mana pada tahap tersebut dilakukan penilaian terhadap rangkaian kegiatan sebelumnya sebagai bahan untuk perbaikan pada siklus kegiatan selanjutnya. Tingkat partisipasi responden dalam tahapan mengevaluasi kegiatan APL-BM di Kepulauan Seribu tergolong rendah. Mayoritas responden jarang menghadiri pertemuan yang diadakan dalam rangka mengevaluasi kinerja program kerja APL-BM yang sudah dan sedang berjalan. Pada saat menghadiri pertemuan, responden juga jarang menanyakan atau meminta penjelasan dari para pihak terkait bila merasa ada situasi yang tidak berjalan sesuai harapan. Demikian pula responden jarang memberikan masukan sebagai upaya perbaikan kegiatan. Jika mengajukan pertanyaan atau masukan, responden juga merasa tidak mendapat apresiasi yang memuaskan. Secara statistik tidak terdapat perbedaan signifikan pada tingkat partisipasi dalam mengevaluasi kegiatan $A P L$ - BM di pada lima kelurahan yang diamati.

\section{Analisis Faktor-Faktor Penentu Partisipasi Masyarakat}

Analisis terhadap faktor-faktor penentu tingkat partisipasi masyarakat pada pengelolaan APL-BM di Kabupaten Administrasi Kepulauan Seribu dilakukan dengan menggunakan pendekatan SEM sehingga diperoleh hasil akhir model struktural dalam bentuk diagram lintasan sebagaimana Gambar 2.

\section{Faktor yang Mempengaruhi Kemampuan Organisasi Masyarakat (X4)}

Dari hasil analisis SEM diperoleh persamaan struktural faktor yang mempengaruhi peubah X4 sebagai berikut :

$$
X 4=0.82 X 3 ; R^{2}=0.67 \ldots \ldots(\text { Persamaan } 1)
$$




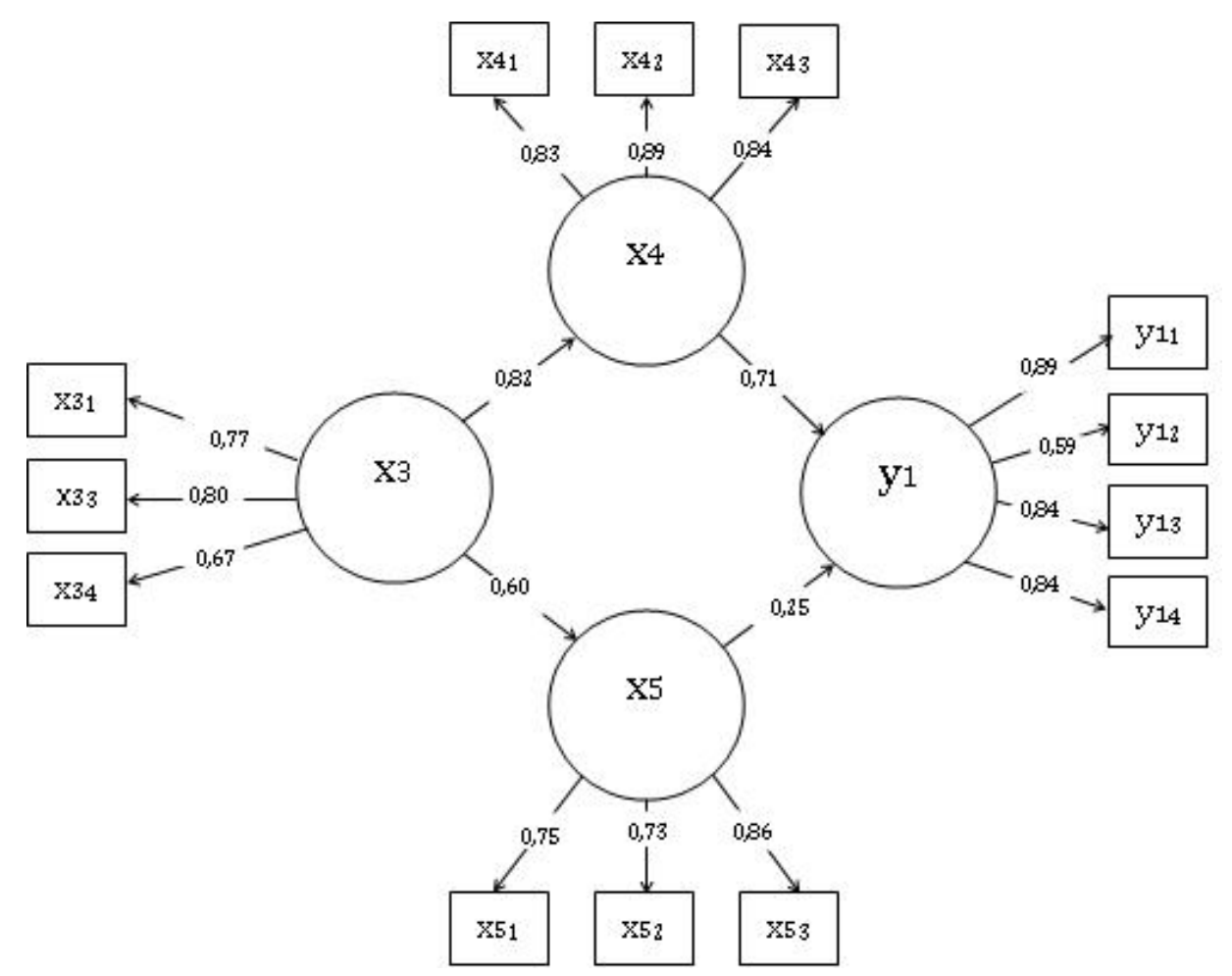

Chi- Square $=152,00, d f=78, p-$ value $=0,032$, RMSEA $=0,069, \mathrm{CFI}=0,99, \mathrm{GFI}=0,91$

\section{Gambar 2. Model Struktural Partisipasi Masyarakat dalam Pengelolaan APL-BM di Kabupaten Administrasi Kepulauan Seribu (Standardized). \\ Figure 2. Structural Model of Community Participation in Managing CB-MPA in Kepulauan Seribu District (Standardized).}

Dari Persamaan 1 tersebut diperoleh informasi obyektif $R^{2}=0,67$ yang menandakan bahwa pengaruh peubah $\mathrm{X} 3$ terhadap $\mathrm{X} 4$ adalah sebesar 0,67 atau $67 \%$ dan sisanya $33 \%$ dipengaruhi oleh faktor lain yang tidak diteliti dalam penelitian ini. Semula diduga peubah Kemampuan Organisasi Masyarakat dalam Pengelolaan APLBM (X4) dipengaruhi oleh peubah Karakteristik Individu (X1), Dinamika Sosial Budaya Masyarakat (X2) dan Kualitas Program Pengelolaan APLBM (X3), namun temuan penelitian menunjukkan bahwa tidak semua semua peubah bebas yang diusung memiliki pengaruh nyata terhadap peubah Kemampuan Organisasi Masyarakat dalam Pengelolaan APL-BM (X4). Oleh karena itu, hipotesis 1 tidak semuanya diterima, hanya terdapat satu peubah yang terbukti berpengaruh positip terhadap kemampuan organisasi masyarakat dalam pengelolaan APL-BM, yaitu peubah Kualitas Program Pengelola APL-BM (X3).

Dari temuan di atas, dapat dinyatakan bahwa kualitas program merupakan faktor penting yang mempengaruhi kemampuan organisasi masyarakat dalam menjalankan perannya sebagai fasilitator utama pengelolaan APL-BM di Kepulauan Seribu. Semakin tinggi kualitas program pengelolaan yang meliputi indikator pendekatan komunikasi program, kesesuaian konsepsi program, intensitas peran penyuluhan maka akan meningkatkan kemampuan organisasi masyarakat dalam pengelolaan APLBM yang meliputi kemampuan teknis, kemampuan manajerial dan kemampuan sosial.

Indikator kualitas program pengelolaan APL-BM yang paling berpotensi mempengaruhi kemampuan organisasi masyarakat adalah kesesuaian konsepsi program. Paradigma pengelolaan sumberdaya perikanankelautan secara kolaboratif-partisipatif yang dimanifestasikan melalui penerapan program APL-BM adalah isu yang relatif baru dengan kompleksitas yang cukup tinggi bagi masyarakat di Kepulauan Seribu. Perubahan paradigma ini tidak mudah dilaksanakan karena membutuhkan perumusan kesepakatan-kesepakatan yang mengakomodasi beragam kepentingan dan perlu didukung kesiapan sumberdaya manusia pengurus 
organisasi masyarakat yang tanggap, saranaprasarana dan skema pembiayaan yang memadai.

Masyarakat menghendaki konsepsi program tersebut mampu diterjemahkan menjadi langkahlangkah praktis pengelolaan sumberdaya yang juga menjamin rasa berkeadilan dalam mendistribusikan manfaat pemulihan sumberdaya tersebut. Isu pemenuhan rasa keadilan dalam mendistribusikan manfaat program sangat berpengaruh pada kemampuan organisasi masyarakat dalam menjalankan perannya sebagai fasilitator program.

Terdapat persoalan beda penafsiran tentang konsepsi pengelolaan sumberdaya melalui implementasi program APL-BM di Kepulauan Seribu pada kelompok-kelompok pemanfaat yang ada. Perbedaan tersebut terutama menyangkut aturan tentang aktivitas yang diizinkan pada areal inti perlindungan. Situasi lapangan yang berkembang dalam tiga tahun terakhir menunjukkan bahwa areal inti tidak steril dari aktivitas selain aktivitas konservasi Kelompok nelayan sebagai kelompok pemanfaat tradisional menganggap bahwa peraturan yang melarang semua pihak untuk melakukan aktivitas ekstraktif pada areal inti tidak berjalan secara konsisten dan memenuhi rasa keadilan.

Kelompok pemanfaat ekowisata bahari adalah kelompok yang paling sering melanggar aturan tersebut dengan membawa wisatawan memasuki areal inti perlindungan untuk wisata snorkeling dan scuva diving karena kualitas terumbu karang di areal tersebut relatif baik sebagai hasil dari upaya transplantasi karang yang dilakukan dan jaraknya cukup dekat dari pulau pemukiman. Perilaku ini memicu kecemburuan dari kelompok pemanfaat tradisional untuk ikut melakukan aktivitas pemanfaatan pada areal inti tersebut baik secara sembunyi-sembunyi maupun terang-terangan. Fakta ini diperkuat dengan sering hilangnya pelampung dan tali baja yang menjadi penanda batas areal inti perlindungan.

Pengamatan penelitian juga menemukan fakta bahwa kelompok nelayan muroami pernah melakukan operasi penangkapan di areal inti perlindungan dengan alasan mereka juga berhak mengambil manfaat dari tingginya produktivitas sumberdaya di kawasan tersebut. Operasi penangkapan ikan di dalam areal inti perlindungan ini merupakan ekspresi ketidakpuasan kelompok nelayan tradisional terhadap penerapan konsepsi pengelolaan APL- BM. Di sisi lain, organisasi masyarakat pengelola tidak mampu bertindak untuk melarang aktivitas tersebut karena ketidakjelasan konsepsi pengelolaan yang menjadi kesepakatan yang diberlakukan.

Isu lain yang menjadi permasalahan pada tingkat akar rumput adalah persoalan pembagian ruang dalam menjalankan usaha perikanan pada masing-masing kelompok. Isu ini berkaitan pembagian ruang usaha antara kelompok usaha budidaya karang komersial dengan kelompok usaha nelayan tangkap dan kegiatan pemanduan wisata bahari. Sejauh ini isu tersebut baru berkembang di Kelurahan Pulau Panggang karena kegiatan budidaya karang komersial baru berkembang di wilayah kelurahan tersebut.

Secara teknis, kelompok usaha budidaya karang komersial membutuhkan ruang khusus yang bebas dari pengaruh aktivitas usaha lain untuk menjamin keberhasilan usahanya. Sementara di sisi lain, belum terbentuk aturan / kesepakatan yang mengakomodasi kebutuhan tersebut. Kelompok budidaya karang komersial mengeluhkan gangguan teknis karena wisatawan dan nelayan tangkap melakukan aktivitas mereka pada jarak yang sangat dekat dengan lokasi usaha mereka. Tindakan ini didasari oleh pandangan bahwa wilayah laut adalah ruang terbuka yang dapat dimanfaatkan oleh semua komponen masyarakat. Fenomena ini menunjukkan bahwa pendekatan pengelolaan sumberdaya alam secara kolaboratif memerlukan pengorganisasian sumberdaya alam dan sosial dengan baik sebagai syarat keberhasilannya.

Indikator kualitas program pengelolaan berikutnya yang berpotensi mempengaruhi kemampuan organisasi masyarakat dalam adalah pendekatan komunikasi program. Temuan penelitian menunjukkan bahwa kinerja pendekatan komunikasi pada program pengelolaan APL tergolong dalam kategori rendah. Sejak awal digulirkannya program APL-BM, proses komunikasi berjalan kurang demokratis karena tidak memberi ruang diskusi yang memadai untuk membahas pertimbangan-pertimbangan pokok yang menjadi acuan teknis penerapan kesepakatan pengelolaan sumberdaya. Proses komunikasi belum memberi ruang yang memadai bagi organisasi masyarakat untuk memahami dan mengembangkan deskripsi tugas, wewenang, kelengkapan sarana-prasarana serta dukungan pembiayaan yang mereka miliki dalam menjalankan tugasnya sebagai fasilitator utama program. Keterbatasan-keterbatasan ini menyebabkan organisasi masyarakat pengelola APL-BM mengalami kesulitan dalam menjalankan 
tugasnya dalam meraih dukungan masyarakat, menegakkan aturan, membangun kerjasama dan mengantisipasi potensi konflik kepentingan pada tingkat akar rumput.

Fenomena komunikasi ini sejalan dengan pendapat Aasetre (2004) yang menyatakan bahwa terdapat hubungan antara kerelaan warga masyarakat untuk berpartisipasi dengan situasi komunikasi yang berjalan dengan baik tanpa distorsi, di mana warga masyarakat dapat dengan bebas bertukar informasi, mengekspresikan pendapatnya dan memiliki akses untuk mempengaruhi proses pengambilan keputusan. Habermas (Greenhalgh et al., 2006) juga menyatakan bahwa keterlibatan masyarakat dalam pembangunan memerlukan situasi komunikasi yang ideal di mana warga dapat saling berdialog tanpa tekanan dan memiliki peluang yang sama untuk diterima pendapatnya.

Indikator kualitas program pengelola APLBM berikutnya yang mempengaruhi kemampuan organisasi masyarakat dalam adalah intensitas peran penyuluhan. Hal ini berarti bahwa intensitas peran penyuluh akan meningkatkan kemampuan organisasi masyarakat dalam mengelola APL-BM. Semakin intens penyuluh menjalankan perannya sebagai fasilitator, edukator dan advokator maka akan semakin meningkat kemampuan teknis, kemampuan sosial dan kemampuan manajerial organisasi masyarakat.

Fakta penelitian di lapangan menunjukkan bahwa interaksi antara penyuluh dengan organisasi masyarakat pengelola maupun kelompok masyarakat pemanfaat sumberdaya berada dalam kategori sedang. Penilaian ini lebih baik bila dibandingkan dengan banyak indikator input program yang lainnya. Hal ini merupakan dampak dari kinerja yang ditunjukkan oleh petugas penyuluhan di lapangan. Pemahaman yang terbentuk di masyarakat pada saat penelitian menunjukkan bahwa petugas penyuluh adalah aparat pemerintah yang paling mudah ditemui di lapangan jika organisasi masyarakat pengelola dan kelompok masyarakat ingin mendiskusikan permasalahan mereka. Petugas penyuluh juga mulai melakukan pendampingan aspek penguatan kemampuan manajemen organisasi masyarakat pengelola dalam menjalankan perannya sebagai fasilitator program dengan mendampingi organisasi masyarakat pada pertemuan-pertemuan yang membahas permasalahan dalam pengelolaan APL-BM maupun permasalahan pengelolaan sumberdaya secara luas.
Secara umum, dapat dikatakan bahwa petugas penyuluhan telah memberikan kontribusi positif dalam proses pengelolaan APL-BM meskipun masih belum optimal dan memiliki banyak keterbatasan. Temuan ini sejalan dengan pendapat Sumardjo (2010) serta Maoyedi dan Azizi (2011) yang menyatakan bahwa kegiatan penyuluhan sebagai instrumen pendidikan non formal berperan dalam membentuk kemampuan organisasi dan perubahan perilaku masyarakat dalam pengelolaan sumberdaya alam ke arah yang lebih baik meliputi peningkatan aspek kognitif, afektif dan psikomotorik/konatif.

\section{Faktor-Faktor Yang Mempengaruhi Motivasi Masyarakat (X5)}

Dari hasil analisis SEM diperoleh persamaan struktural faktor yang mempengaruhi peubah motivasi masyarakat dalam pengelolaan DPL - BM (X5) sebagai berikut:

$$
X 5=0,60 X 3 ; R^{2}=0,37 \ldots \ldots(\text { Persamaan } 2)
$$

Dari Persamaan 2 diperoleh informasi obyektif $R^{2}=0,37$ menandakan bahwa pengaruh peubah $\mathrm{X} 3$ terhadap peubah $\mathrm{X} 5$ adalah sebesar 0,37 atau $37 \%$ dan sisanya $63 \%$ dipengaruhi oleh faktor lain yang tidak diteliti dalam penelitian ini. Semula diduga peubah Motivasi Masyarakat dalam Pengelolaan APL-BM (X5) dipengaruhi oleh peubah Karakteristik Individu (X1), peubah Dinamika Sosial Budaya Masyarakat (X2) dan peubah Kualitas Program Pengelolaan APL-BM (X3), namun temuan penelitian sebagaimana persamaan struktural 2 di atas menunjukkan tidak semua semua peubah bebas yang diusung dalam penelitian memiliki pengaruh nyata terhadap motivasi masyarakat dalam pengelolaan APL - BM (X5). Oleh karena itu, hipotesis 2 tidak semuanya diterima, hanya satu peubah yang terbukti berpengaruh positip terhadap terhadap motivasi masyarakat dalam pengelolaan $\mathrm{APL}$ - BM, yaitu peubah Kualitas Program Pengelolaaan APL - BM (X3).

Dari temuan di atas dapat dinyatakan bahwa kualitas program merupakan faktor penting dalam meningkatkan motivasi masyarakat. Semakin tinggi kualitas program pengelolaan APL-BM yang meliputi pendekatan komunikasi program, kesesuaian konsepsi program dan intensitas peran penyuluhan maka semakin tinggi pula motivasi masyarakat yang meliputi motivasi untuk meningkatkan pendapatan, motivasi untuk 
mendapatkan pengakuan atas kredibilitas dan motivasi untuk melestarikan sumberdaya.

Indikator kualitas program yang paling berpotensi mempengaruhi motivasi masyarakat adalah kesesuaian konsepsi program. Seperti yang telah disebutkan sebelumnya, isu kesesuaian konsepsi program merupakan isu utama yang mempengaruhi respons masyarakat terhadap program tersebut. Masyarakat cukup memahami tujuan dasar dari program APL- BM yaitu memulihkan produktivitas sumberdaya sehingga diperlukan upaya proteksi terhadap kawasan tertentu sebagai "bank ikan dan terumbu karang". Dalam pandangan masyarakat, tindakan proteksi terhadap kawasan tertentu juga sebaiknya diikuti dengan upaya khusus meningkatkan produktivitas sumberdaya pada kawasan lain yang berstatus sebagai areal pemanfaatan.

Usulan yang diajukan masyarakat adalah agar mereka diberikan kepercayaan oleh pemerintah untuk mengelola kawasan fish shelter di areal pemanfaatan secara bersama-sama sebagai mekanisme imbal balik dari kesediaan mentaati aturan pembatasan akses pemanfaatan pada areal inti perlindungan. Pemberian wewenang kelola produksi pada fish shelter ini diharapkan akan meningkatkan motivasi masyarakat untuk berpartisipasi pada pengelolaan APL - BM karena pada jangka pendek ada dukungan untuk memenuhi kebutuhan hidupnya selama menunggu masa pulih produktivitas sumberdaya dan pada jangka panjang ada jaminan untuk meningkatkan kesejahteraan hidup. Temuan penelitian ini sejalan dengan hasil penelitian Saad (2009) yang menyatakan bahwa terdapat hubungan antara motivasi untuk meningkatkan kesejahteraan pada masyarakat nelayan dengan kontrol pada akses pemanfaatan sumberdaya pada program konservasi.

Indikator kualitas program berikutnya yang berpotensi mempengaruhi motivasi masyarakat adalah pendekatan komunikasi program. Semakin baik pendekatan komunikasi program maka akan semakin meningkatkan motivasi masyarakat dalam pengelolaan APL-BM. Temuan penelitian menunjukkan bahwa kinerja pendekatan komunikasi pada program pengelolaan APL tergolong dalam kategori rendah. Proses komunikasi berjalan kurang demokratis karena tidak memberi ruang diskusi yang memadai untuk membahas pertimbanganpertimbangan pokok yang mendasari penerapan program. Ide pembatasan akses pemanfaatan sumberdaya pada areal inti perlindungan belum dikomunikasi dengan baik kepada kelompokkelompok pemanfaat sumberdaya, sehingga masyarakat belum sepenuhnya memahami bahwa upaya tersebut bertujuan menjamin keberlanjutan manfaat, bukan sebagai upaya mempersulit masyarakat dalam mencari penghidupan.

Pendekatan komunikasi program tidak menyediakan informasi yang membantu masyarakat dalam membangun pemahaman baru bagaimana mereka memberi respon yang tepat dalam tataran praksis. Pendekatan komunikasi tidak mampu memfasilitasi terbentuknya situasi komunikasi yang ideal bagi kelompok-kelompok masyarakat pemanfaat sumberdaya untuk mendiskusikan perkembangan-perkembangan di lapangan sebagai konsekwensi perbedaan kepentingan yang muncul di tingkat akar rumput. Hal ini menegaskan temuan dari Crawford et al. (2006) tentang pentingnya peran komunikasi dalam program mempengaruhi keberhasilan penerapan program daerah perlindungan laut berbasis masyarakat di Indonesia.

Indikator kualitas program pengelola APLBM berikutnya yang berpotensi mempengaruhi kemampuan organisasi masyarakat adalah intensitas peran penyuluhan perikanan - kelautan. Semakin intens peran penyuluhan maka akan semakin meningkatkan motivasi masyarakat dalam pengelolaan APL-BM. Intensitas peran penyuluhan berpotensi meningkatkan motivasi masyarakat melalui perannya sebagai fasilitator dalam proses-proses pembelajaran sosial, sehingga tumbuh motivasi untuk meningkatkan pendapatan, memperoleh pengakuan atas kredibilitas dan melestarikan sumberdaya perikanan - kelautan sebagai warisan anak cucunya.

\section{Faktor-Faktor Yang Mempengaruhi Partisipasi Masyarakat (Y1)}

Dari hasil analisis SEM diperoleh persamaan struktural faktor - faktor yang mempengaruhi peubah partisipasi masyarakat (Y1) sebagai berikut:

$\mathrm{Y} 1=0,71 \mathrm{X} 4+0,25 \mathrm{X} 5 ; \mathrm{R}^{2}=0,79 \ldots($ Persamaan 3$)$

Dari Persamaan 3 diperoleh informasi obyektif $R^{2}=0,79$ yang menandakan bahwa pengaruh bersama peubah Kemampuan Organisasi Masyarakat (X4) dan peubah Motivasi Masyarakat (X5) terhadap peubah Partisipasi Masyarakat (Y1) adalah sebesar 0,79 atau $79 \%$ dan sisanya $21 \%$ dipengaruhi oleh faktor lain yang tidak diteliti 
dalam penelitian ini. Secara parsial, terlihat bahwa koefisien lintas peubah $\mathrm{X} 4$ adalah 0,71 yang berarti besarnya pengaruh peubah $\mathrm{X} 4$ terhadap peubah Y1 adalah $0,71^{2}=50,41 \%$. Selain itu, secara parsial juga terlihat bahwa koefisien lintas peubah X5 adalah 0,25 yang berarti besarnya pengaruh peubah $\mathrm{X} 5$ terhadap peubah $\mathrm{Y} 1$ adalah $0,25^{2}=$ $6,25 \%$.

Mengacu pada persamaan struktural 3 tersebut maka secara statistik peubah-peubah bebas sebagaimana yang diusulkan dalam hipotesis 3 terbukti memiliki pengaruh nyata terhadap partisipasi masyarakat dalam pengelolaanAPL-BM, dengan demikian hipotesis 3 diterima. Pengaruh kedua peubah tersebut bersifat langsung, di mana pengaruh terbesar ada pada peubah kemampuan organisasi masyarakat (X4) dan kemudian diikuti oleh peubah motivasi masyarakat (X5).

Kemampuan manajerial merupakan indikator kemampuan organisasi masyarakat yang paling berpotensi mempengaruhi partisipasi masyarakat. Semakin tinggi tingkat kemampuan manajerial organisasi masyarakat dalam pengelolaan APL-BM maka akan semakin meningkatkan partisipasi masyarakat. Organisasi masyarakat berperan penting sebagai fasilitator dalam proses pengelolaan sumberdaya perikanan-kelautan yang berbasis masyarakat. Proses mengorganisasikan masyarakat bukan hanya membentuk organisasi, tetapi juga membekali dengan kemampuan manajerial yang baik dalam mengembangkan kemandirian dan mengembangkan kapasitas organisasi. Kemampuan tersebut merupakan prasyarat dasar dalam kerja organisasi memfasilitasi kedudukan masyarakat sebagai subyek utama pembangunan.

Fakta penelitian menunjukkan bahwa indikator kemampuan manajerial organisasi masyarakat dalam mengelola sumberdaya melalui program APL-BM berada dalam kategori rendah. Pada kenyataannya, organisasi masyarakat memang belum memiliki kemampuan untuk untuk mengelola sumberdaya sosial dan sumberdaya alam yang dimiliki sebagai modal positif untuk menjalankan fungsi kerja fasilitasi pengelolaan sumberdaya perikanan - kelautan yang dibebankan kepadanya.

Secara teoritik kemampuan organisasi masyarakat dalam memfasilitasi pengelolaan sumberdaya perikanan - kelautan melalui penerapan program APL-BM dapat ditingkatkan dengan proses pendidikan non formal berupa penyelenggaraan pelatihan dan pendampingan sebagai proses pembelajaran. Namun pada kenyataannya berbagai pelatihan yang diberikan dapat dikatakan belum memberikan dampak perubahan perilaku yang sesuai yang diharapkan.

Beberapa jenis pelatihan yang diberikan sudah sesuai dengan kebutuhan belajar organisasi masyarakat, tetapi jenjang materi yang disampaikan hanya di tingkat pengetahuan dasar dan belum mampu memfasilitasi perubahan sikap dan penguasaan ketrampilan yang dibutuhkan. Berdasarkan pengamatan selama penelitian, diperoleh gambaran bahwa lembaga-lembaga penyelenggara pelatihan belum memiliki kurikulum belajar yang berjenjang, berlanjut dan menyeluruh.

Frekwensi, daya tampung dan durasi pelatihan juga terbatas sehingga belum mampu memenuhi kebutuhan belajar organisasi masyarakat. Pelatihan yang diselenggarakan tidak diikuti dengan pendampingan dan penyediaan sarana prasarana yang berfungsi memperkuat proses belajar lanjutan. Pengurus organisasi masyarakat tidak dapat mendiskusikan masalah - masalah yang mereka hadapi terkait dengan penerapan materi pelatihan yang sudah diperoleh sebelumnya. Pengadaan sarana dan prasaran pendukung pelatihan juga tidak berjalan dengan baik sehingga peserta pelatihan kesulitan menerapkan ketrampilan yang diperoleh. Selain itu, seringkali informasi tentang pelatihan - pelatihan yang diselenggarakan tidak disosialisasikan secara luas dan transparan sehingga pelatihan tidak diikuti oleh individu yang mewakili kepengurusan organisasi masyarakat pengelola APL-BM.

Indikator berikutnya yang berpotensi mempengaruhi partisipasi masyarakat dalam pengelolaan APL-BM adalah kemampuan sosial. Temuan penelitian menunjukkan bahwa kemampuan sosial organisasi masyarakat dapat menjadi salah satu kekuatan pendorong atau kekuatan yang memotivasi masyarakat untuk berpartisipasi dalam program APL-BM. Kemampuan sosial organisasi masyarakat berkaitan dengan kemampuan untuk membangun berinteraksi positif di antara kelompok - kelompok pemanfaat di dalam masyarakat maupun dengan pemangku kepentingan dari luar masyarakat. Hal ini sejalan dengan pendapat Ife dan Toseriero (2006) bahwa kemampuan masyarakat untuk mengembangkan unsur "perekat" akan 
mendorong masyarakat memperkuat inisiatif dan kesukarelaan dalam berpartisipasi di lingkungan sosialnya.

Fakta penelitian menunjukkan bahwa indikator kemampuan sosial organisasi masyarakat dalam mengelola sumberdaya melalui program APLBM berada dalam kategori rendah. Penelusuran lebih lanjut menunjukkan bahwa kemampuan sosial yang rendah ini setidaknya disebabkan oleh dua hal. Pertama; proses pemilihan pengurus organisasi masyarakat tidak terselenggara dengan baik sehingga formatur kepengurusan yang terbentuk tidak sepenuhnya mewakili keberadaan kelompokkelompok pemanfaat yang ada di masyarakat atau dengan kata lain susunan pengurus tidak memiliki legitimasi yang kuat dalam sistem sosialnya. Kedua; kemampuan sosial sumberdaya manusia pengurus organisasi masyarakat dalam mengelola konflik juga terbatas dan tidak dikembangkan melalui proses pendidikan non - formal yang terencana dengan baik sehingga seringkali tidak mampu merespon dinamika sosial yang semakin kompleks. Hal serupa dikemukakan oleh Renn (2006) serta Soma dan Vatn (2009) bahwa keterwakilan kelompok kelompok masyarakat perlu diakomodasi dalam mendisain kebijakan pengelolaan lingkungan yang partisipatif.

Indikator lainnya yang mempengaruhi partisipasi masyarakat dalam pengelolaan APLBM adalah kemampuan teknis. Kemampuan teknis organisasi masyarakat dalam mengelola sumberdaya dapat ditingkatkan kapasitasnya melalui proses belajar informal dan belajar non formal (Gartaula, 2006). Proses belajar informal terjadi secara turun temurun yang bersifat praksis atau learning by doing dan telah menjadi bagian dari perilaku mereka sehari-hari yang berkaitan dengan kegiatan pemanfaatan sumberdaya perikanan - kelautan . Proses belajar non-formal dapat berbentuk pelatihan dan pendampingan yang bertujuan melakukan transfer pengetahuan dan ketrampilan baru yang dibutuhkan dalam pengelolaan sumberdaya. Temuan penelitian menunjukkan organisasi masyarakat pengelola APL-BM memiliki kemampuan teknis yang cukup memadai.

Motivasi untuk melestarikan sumberdaya merupakan indikator yang berpotensi memiliki pengaruh paling besar terhadap partisipasi masyarakat. Semakin tinggi motivasi untuk melestarikan sumberdaya, maka akan semakin tinggi tingkat partisipasi masyarakat dalam pengelolaan APL-BM. Pendapat ini diperkuat oleh temuan penelitian dari Sangadji (2010) dan Suprayitno (2011) yang menyatakan bahwa aspek kemauan atau motivasi untuk melestarikan sumberdaya alam sebagai warisan anak cucu adalah faktor penting yang mendorong tingkat partisipasi dalam pengelolaan sumberdaya alam berbasis masyarakat.

Motivasi melestarikan sumberdaya juga disebabkan secara psikologis masyarakat merasa memiliki ikatan emosional dan sosial dengan keberadaan sumberdaya perikanan - kelautan karena selama ini penghidupan mereka bergantung pada keberadaan sumberdaya tersebut. Temuan ini, dengan demikian menjelaskan bahwa apabila dalam diri individu dan kelompok masyarakat terdapat kesadaran akan pentingnya eksistensi dan keberlanjutan maka masyarakat akan tetap terdorong untuk menjaganya dan kemudian berpartisipasi dalam pengelolaannya. Hal ini sejalan dengan temuan Evans et al (2008) yang mengemukakan bahwa kesadaran atas eksistensi dan keberlanjutan sumberdaya akan mendorong masyarakat untuk berpartisipasi pada kegiatan pengelolaan lingkungan pesisir.

Indikatorkedua darimotivasi masyarakatyang berpengaruh positip terhadap tingkat partisipasi masyarakat dalam pengelolaan APL-BM adalah motivasi untuk meningkatkan pendapatan. Semakin tinggi motivasi masyarakat untuk meningkatkan pendapatan rumah tanganya maka akan semakin tinggi tingkat partisipasi masyarakat dalam pengelolaan APL - BM. Pemanfaatan sumberdaya perikanan-kelautan adalah sumber utama penghidupan kelompok-kelompok masyarakat di Kepulauan Seribu. Keberadaan dan produktivitas sumberdaya alam tersebut merupakan pengaman atau jaminan ekonomi rumah tangga. Semakin baik daya dukung lingkungan dan produktivitas sumberdaya perikanan - kelautan yang ada di sekeliling mereka maka masyarakat akan merasa aman (the wish for security) dalam hal pemenuhan kebutuhan rumah tangga. Pada tahap berikutnya motivasi tersebut berkembang menjadi motivasi untuk meningkatkan pendapatan.

Indikator motivasi masyarakat berikutnya yang berpotensi memiliki pengaruh terhadap tingkat partisipasi masyarakat dalam pengelolaan APL-BM adalah motivasi untukmendapatkan pengakuan atas kredibilitas mereka. Fakta penelitian menunjukkan bahwa motivasi masyarakat untuk mendapatkan pengakuan atas kredibilitas dalam mengelola 
sumberdaya perikanan berada dalam kategori sedang. Hal ini menjelaskan bahwa kelompokkelompok masyarakat pemanfaat sumberdaya di Kepulauan Seribu termotivasi untuk terus dapat berpartisipasi dalam mengelola sumberdaya alam secara lestari karena ingin membuktikan bahwa mereka memiliki potensi dan kemampuan yang memadai sebagai mana pemangku kepentingan yang lain (the wish for recognition) kemampuannya sebagai pihak yang mampu mengelola sumberdaya alam dengan baik. Santrock (2008) menyebut motif ini sebagai motif kompetensi.

Hampirkeseluruhan masyarakat diKepulauan Seribu telah melakukan praktek pemanfaatan sumberdaya perikanan-kelautan yang dilandasi oleh nilai-nilai budaya dan pengetahuan lokal dalam kurun waktu yang sangat lama dari generasi ke generasi, dengan demikian telah terbentuk budaya yang menyatu dalam kehidupan sehari-hari mereka. Kemampuan praktis dalam memanfaatkan sumberdaya tersebut merupakan bukti nyata bahwa masyarakat memiliki kemampuan yang dapat diandalkan dan merupakan modal sosial yang perlu dipertimbangkan dalam penyusunan kebijakan pengelolaan sumberdaya tersebut.

\section{KESIMPULAN DAN IMPLIKASI KEBIJAKAN}

Tingkat partisipasi masyarakat dalam pengelolaan Areal Perlindungan Laut - Berbasis Masyarakat (APL-BM) di wilayah Kabupaten Administrasi Kepulauan Seribu tergolong rendah pada semua tahapan partisipasi atau masih tergolong dalam partisipasi pasif. Faktor-faktor yang mempengaruhi rendahnya tingkat partisipasi masyarakat adalah sebaran tingkat kemampuan organisasi masyarakat dalam pengelolaan yang meliputi kemampuan teknis (tingkat kemampuan sedang), kemampuan manajerial (tingkat kemampuan rendah) dan kemampuan sosial (tingkat kemampuan rendah) serta rendahnya tingkat motivasi masyarakat meliputi motivasi untuk meningkatkan pendapatan (tingkat motivasi rendah), motivasi untuk mendapat pengakuan atas kredibilitas (tingkat motivasi rendah) dan motivasi untuk melestarikan sumberdaya (tingkat motivasi rendah). Rendahnya tingkat kemampuan organisasi dan motivasi masyarakat dipengaruhi oleh rendahnya kualitas pendekatan komunikasi program, kesesuaian konsepsi program dan intensitas peran penyuluhan

\section{SARAN}

Pengembangan partisipasi masyarakat dalam pengelolaan APL-BM di wilayah Kabupaten Administrasi Kepulauan Seribu harus dibangun dengan mempertimbangkan konsepsi pengelolaan yang mampu menjamin pemenuhan kebutuhan sosial-ekonomi masyarakat melalui manfaat program dan mengakomodasi rasa keadilan dalam pendistribusian manfaat tersebut bagi kelompok-kelompok pemanfaat sumberdaya dan pemangku kepentingan yang ada. Dalam tataran praksis, upaya pengembangan partisipasi tersebut terutama dilakukan dengan merevitalisasi peraturan pengelolaan APL-BM sehingga mampu mengakomodasi kepentingan secara berkeadilan, memperbaiki kinerja pendekatan komunikasi program serta memberikan hak kelola terbatas terbatas pada kawasan fish shelter kepada masyarakat sebagai insentif atas kesediaannya berpartisipasi.

\section{DAFTAR PUSTAKA}

Aasetre, J. 2006. Perceptions of Communication in Norwegian Forest Management. Journal of Forest Policy and Economics. Vol 8. http/ www.elsevier.com/locate/forpol.

Aldon, M., A.C. Fermin and R.F. Agbayani. 2011. Socio-Cultural Context of Fisher's Participation in Coastal Resources Management in Aniny-y, Antique in West Central Philippines. Journal of Fiheries Research. 107. http/www.elsevier.com/ locate/fishres.

Amanah, S. 2006. Pengembangan Masyarakat Pesisir Berdasarkan Kearifan Lokal di Pesisir Buleleng, Provinsi Bali. Disertasi. Institut Pertanian Bogor. Bogor.

Alpizar, M.A.Q. 2006. Participation and Fisheries Management in Costa Rica : from Theory to Practice. Jounal of Marine Policy. 30. http/ www.elsevier.com/locate/marpol.

Clifton, J. 2003. Prospects for Co-management in Indonesia's Marine Protected Areas. Journal Of Marine Policy. 27. http/www.elsevier.com/ locate/marpol.

Crawford, B., M. Kasmidi, F. Korompis and R.B. Polnac. 2006. Factors Influencing in Establishing Community Based Marine Protected Area in Indonesia. Journal of Coastal Management. 34. Taylor and Francis. 
Evans, S.M., S.Gebbels and J.M. Stockill. 2008. Our Shared Responsibility : Participation in Ecological Projects as a Means of Empowering Communities to Contribute to Coastal Management Processes. Journal of Marine Pollution Bulletin Vol 3 (7). http/www. elsevier.com/locate/marpolbud.

Fauzy, A and E.A. Buchary. 2002. A Socioeconomic Perspective of Environmental Degradation at Kepulauan Seribu Marine National Park, Indonesia. Journal of coastal Management. 30. Taylor and Francis.

Gartaula, H.N. 2008. Practices of Participation in Coastal Area Management: Experience from Kenya. Journal of Ocean and Coastal Management. 5. http/www.elsevier.com/ locate/ocecoaman.

Glaser, M., W. Baitotiningsih, S.C.A. Ferse, M. Neil and R. Deswandi. 2010. Whose Sustainibility? Top-Down Participation and Emegent Rules in Marine Protected Area Management in Indonesia. Journal of Marine policy. 34. http/www.elsevier.com/locate/marpol.

Greenhalgh, T., N. Robb and G. Scambler. 2006. Communicative and Strategic Action in Interpreted Consultations in Primary Health Care. Journal of Social Science and Medicine. 63. http/www.elsevier.com/locatesocscimed.

Hartoto, D.E., L. Adrianto, D. Kalokoski dan T. Yunanda. 2009. Peningkatan Kapasitas untuk Pengarus-utamaan Ko-Manajemen Perikanan di Indonesia. Direktorat Sumberdaya Ikan DKP. Jakarta.

Ife, J and F. Toseriero. 2008. Community Development: Alternatif Pengembangan Masyarakat di era Globalisasi. Pustaka Pelajar. Yogjakarta.

Moayedi, A.A. and M. Azizi. 2011. Participatory Managemen Opportunity for Optimizing in Agricultural Extension Education. Journal of Procedia Social and Behavioral Science. 15. http/www.elsevier.com

Nazir, M. 1985. Metode Penelitian. Ghalia Indonesia. Jakarta.
Pomeroy, R. dan R. Rivera-Guieb. 2006. Fisheries Co - Management : A Practical Handbook. CABI Publishing. Cambridge.

Renn, O. 2006. Participatory Processes for Designing Environmental Policies. Journal of Land Use Policy. 23. http/www.elsevier. com/locate/landusepol.

Saad, S. 2009. Hak Pemeliharaan dan Penangkapan Ikan. LkiS. Yogjakarta.

Sangadji, M.N. 2010. Partisipasi Masyarakat dalam Pengelolaan Taman Nasional dengan Pola Kemitraan di Kepulauan Togean Sulawesi Tengah. Disertasi. Institut Pertanian Bogor. Bogor.

Santrock, J.W. 2008. Psikologi Pendidikan. Terjemahan dari : Educational Psychology. Wibowo T, penerjemah. Kencana Prenada Media Group. Jakarta.

Soma, K and A. Vant. 2009. Local Democracy implication for Coastal Zone Management : A Case Study in Shoutern Norway. Journal of land Use Policy 26. http/www.elsevier. com/locate/landusepol.

Sumardjo. 2010. Penyuluhan Menuju Pengembangan Kapital Manusia dan Kapital Sosial dalam Mewujudkan Kesejahteraan Rakyat. Orasi IImiah Guru Besar Tetap Fakultas Ekologi Manusia Intitut Pertanian Bogor, 18 September 2010. Institut Pertanian Bogor. Bogor.

Suprayitno, A.R. 2011. Model Peningkatan Partisipasi Petani Sekitar Hutan dalam Pengelolaan Hutan Kemiri Rakyat. Disertasi. Institut Pertanian Bogor. Bogor.

Terangi. 2009. Terumbu Karang Jakarta. Yayasan Terangi. Jakarta.

Zanettel, B.A. and B.A Knuth. 2004. Participation Rhetoric or Community-Based Management Reality? Influences on Willingness to Participate in a Venezuelan Freshwater Fishery. Journal of World Development. 32. http/www.elsevier.com/locate/worlddev. 